\title{
The Islamic Worldview of God, Man and Nature, and Their Relationships
}

\author{
Kabuye Uthman Sulaiman*
}

Department of Fundamental and Inter-Disciplinary Studies, Kulliyyah of Islamic Revealed Knowledge and Human Sciences, International Islamic University Malaysia

DOI: $10.36347 /$ sjahss.2020.v08i12.001

| Received: 05.12.2020 | Accepted: 16.12.2020 | Published: 19.12.2020

*Corresponding author: Kabuye Uthman Sulaiman

\section{Abstract}

The thrust of this study is: first, to describe the Islamic worldview of God, Man and the world, and their relationships. Its objectives are twofold: first, to delineate God-mankind relationship, God-world relationship, al-Dunya (this world)-al-Akhirah (the world hereafter) relationship, man-world relationship and man-man relationship or interpersonal relationship. Understanding these relationships is part and parcel of the Islamic theory of knowledge exposition and the discourse of Islamic civilization. Second, to provide the correct answers to the following deep questions: what is Man's place in the universe? And, what are the things that set humans apart from other creatures on earth? Third, to expound the Qur'anic view on the uniqueness of human beings. The study contends that: first, human beings are characterized by three things, namely body, spirit and intellect or cognitive ability. Their bodies and souls connect them to the physical and the metaphysical worlds respectively, while their intellect enables them to acquire knowledge, formulate ideas or think creatively, dominate nature (develop the earth), reason, reflect, ponder and contemplate, and distinguish right from wrong, moral from immoral behaviour or truth from falsehood; it prevents them from blind following of forefathers and lower desires, which is termed as jahiliyyah. Hence, they are required to work towards the development of these three aspects, namely body, soul and intellect. They are commanded to be grateful to Allah for endowing them with the intellect as it separates them from animals and they are forbidden from performing any act that could result into its impairment or destruction.

Keywords: Dual nature of mankind, God-mankind relationship, God-world relationship, Dunya (worldly)-Akhirah (Hereafter) relationship, man-nature relationship, man-man relationship, intellect.

Copyright (C) 2020 The Author(s): This is an open-access article distributed under the terms of the Creative Commons Attribution 4.0 International License (CC BY-NC 4.0) which permits unrestricted use, distribution, and reproduction in any medium for non-commercial use provided the original author and source are credited.

\section{INTRODUCTION}

It is not possible to build a correct framework on which to base one's life without first understanding ourselves, our relationship with God (Allah) and the world we live in. This paper, therefore, aims to describe the Islamic worldview of God-mankind relationship, God-world relationship, al-Dunya (this world)-alAkhirah (the hereafter) relationship, man-nature relationship and man-man relationship or interpersonal relationship. Worldview is the lens through which a particular group of individuals "understand the truth about themselves, the world in which they live and their relationships to the world and to each other $\left[{ }^{1}\right]$ ". It is

${ }^{1}$ Massimo Pigliucci (November 19, 2009), Science and philosophy: what's the difference? Retrieved on

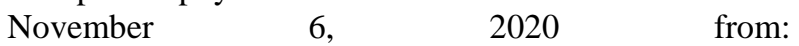
https://www.psychologytoday.com/us/blog/rationallyspeaking/200911/the-difference-between-science-andphilosophy hoped that this description will enable the readers to have a better understanding of the world, know their responsibilities to God (Allah), themselves and the world, and appreciate the differences among people.

\section{THE RELATIONSHIP BETWEEN GOD (ALLAH) AND MANKIND}

It is of utmost importance to find the correct answers to these big questions: what is God's relationship with mankind? How should mankind relate itself to God? Or, through what acts does mankind draw close to God? Why is it important for mankind to establish a relationship with God? Only when mankind finds the correct answers to these big questions and establishes its relationship with God (Allah), does mankind's life becomes meaningful.

Allah distinguished human beings from other creatures: first, by endowing them with intellect or the cognitive abilities to learn, apply and store the knowledge. It is the faculty that enables them to think 
or reason, understand, act morally (control their lust and desire), draw lessons from life experiences, interpret sensory information, solve problems and make decisions.

The Arabic verbs for reasoning and understanding are ya'qilun, ta'qilun, 'aqalu, ya'qiluha and na'qilu. 'Aql and 'iqal are Arabic nouns referring to intellect or mind and a rope that ties a camel respectively. While these two nouns are different in meanings, they are very closely related. Both imply prevention. The aim of 'iqal is to secure the camel; to prevent it from running away. Similarly, the aim of 'aql is to secure human beings from deviation or wrongdoings that might ruin them in this life and in the next; it prevents them from what does not correspond to fitrah or innate knowledge and shari'ah, Divine legislation; it elevates them to the level of humanity. That is, the level above that of the beasts which act according to their appetites. Other functions of the intellect encapsulate human ability to dominate nature, ascertain the truth and reflect on the signs of Allah such as the Qur'an, the universe and the creation of human beings. Allah says (interpretation of the meaning):

"Do they not consider the Qur'an (with care)? Had it been from other Than Allah, they would surely have found therein Much discrepancy." (Qur'an, 4:82).

"Soon will We show them our Signs in the (furthest) regions (of the earth), and in their own souls, until it becomes manifest to them that this is the Truth. Is it not enough that thy Lord doth witness all things?" (Qur'an, 41:53).

Second, by revealing Books or shari'ah for their guidance; that is, to bring them forth from the depths of darkness (tyranny, exploitation, idol worship, etc.) into the light (uprightness, monotheism, etc.) or in other words, to govern the behavior of individuals, families, groups and communities or the interactions between them. Shari'ah is generally described as Allah's guidance to mankind: "This is the Book; in it is guidance sure, without doubt, to those who fear Allah." (Qur'an, 2:2). It is the criterion by which human actions are to be judged: "Blessed is He who sent down the criterion to His servant, that it may be an admonition to all creatures." (Qur'an, 25:1). Here it worth noting that shari'ah is the code of life upon which the human nobility and salvation are dependent. Life without shari 'ah is without direction or purpose.

Third, by endowing them with free will or the freedom to choose one of the two options of either righteousness or unrighteousness, good or evil, gratefulness or ungratefulness, belief or disbelief, submission or rebellion. Allah says (interpretation of the meaning): "We showed him the Way: whether he be grateful or ungrateful (rests on his will)." (Qur'an, 73:3). Nevertheless, He made them responsible and accountable for their own actions: "It is He Who hath made you (His) agents, inheritors of the earth: He hath raised you in ranks, some above others: that He may try you in the gifts He hath given you: for thy Lord is quick in punishment: yet $\mathrm{He}$ is indeed Oft-forgiving, Most Merciful.” (Qur'an, 6:165).

From the Islamic perspective the relationship between God (Allah) and mankind is that of the Creator and the created, the Sustainer and sustained, Master and slave. Allah says (interpretation of the meaning):

"That is Allah, your Lord! there is no god but He, the Creator of all things: then worship ye Him: and He hath power to dispose of all affairs." (Qur'an, 6:102).

"...For to Allah belongeth the dominion of the heavens and the earth, and all that is between. He createth what He pleaseth. For Allah hath power over all things." (Qur'an, $5: 17)$.

It is crystal clear from the above verses that Allah is $a l-R a b b$, the Lord, the Sovereign, the Creator, the Owner and the Sole Controller of everything in this world and beyond, and therefore, al-Ilah, the only Being worthy of worship; second.

True nobility lies in being submissive to Allah; that is to say, bowing down and prostrating to Him, doing what He has commanded and avoiding what $\mathrm{He}$ has forbidden. According to the following verse, nobility does not lie in one's race, ethnicity, ancestry or gender:

"O mankind! We created you from a single (pair) of a male and a female, and made you into nations and tribes, that ye may know each other (not that ye may despise (each other). Verily the most honoured of you in the sight of Allah is (he who is) the most righteous of you. And Allah has full knowledge and is well acquainted (with all things)." (Qur'an, 49:13).

Human beings lose their nobility when they submit themselves to anything other than Allah. This includes submission to one's hawa al-Nafs (lower desires and ego) and material things (being materialistic):

"Then seest thou such a one as takes as his god his own vain desire? Allah has, knowing (him as such), left him astray, and sealed his hearing and his heart (and understanding), and put a cover on his sight. Who, then, will guide him after Allah (has withdrawn 
Guidance)? Will ye not then receive admonition?" (Qur'an, 45:23).

Narrated Abu Hurayrah (may Allah be pleased with him): The Prophet (peace and blessings be upon him) said: "Let the slave of Dinar and Dirham of Quantify and Khamisa (i.e. money and luxurious clothes) perish for he is pleased if these things are given to him, and if not, he is displeased!" [ [ ].

The feeling that we are related to God (Allah), that $\mathrm{He}$ is our Creator and that we are part of His creation, is fitriyy, inherent in human nature. Allah says (interpretation of the meaning):

"When thy Lord drew forth from the Children of Adam - from their loins their descendants, and made them testify concerning themselves, (saying): "Am I not your Lord (who cherishes and sustains you)?"- They said: "Yea! We do testify!" (This), lest ye should say on the Day of Judgment: "Of this we were never mindful": Or lest ye should say:" "Our fathers before us may have taken false gods, but we are (their) descendants after them: wilt Thou then destroy us because of the deeds of men who were futile?"' (Qur'an, 7:172-173).

Human beings are commanded to constantly remember Allah and relate themselves to $\mathrm{Him}$ by executing His commands; that is, by surrendering and submitting themselves fully to Him, or in other words, by following His Guidance.

"Say: "Shall we indeed call on others besides Allah, - things that can do us neither good nor harm, - and turn on our heels after receiving guidance from Allah. - like one whom the evil ones have made into a fool, wandering bewildered through the earth, his friends calling, come to us, (vainly) guiding him to the path." Say: "(Allah)'s guidance is the (only) guidance, and we have been directed to submit ourselves to the Lord of the worlds" (Qur'an, 6:71).

It is worth mentioning that one of aims of Allah's guidance is to preserve Man's dignity. Therefore, without adherence to Allah's guidance, a

\footnotetext{
${ }^{2}$ Sahih al-Bukhari, kitab al-Jihad wa al-Sayr (Book of fighting for the Cause of Allah), bab al-Hirasat fi alGhazwi fi sabilillah (Chapter on vigilance during holy
} battles in Allah's Cause). civilized life is not possible. The following speech of Ja'far bin Abi Talib in the court of Najashi, the Christian king of Abyssinia (Ethiopia), provides a glimpse of the role and importance of Allah's guidance and the Prophet Muhammad (peace and blessings be upon him)'s role in life transformation:

"O King! we were plunged in the depth of ignorance and barbarism; we adored idols, we lived in unchastity, we ate the dead bodies, and we spoke abominations, we disregarded every feeling of humanity, and the duties of hospitality and neighborhood were neglected; we knew no law but that of the strong, when Allah raised among us a man, of whose birth, truthfulness, honesty, and purity we were aware; and he called to the Oneness of Allah, and taught us not to associate anything with $\mathrm{Him}$. "He forbade us the worship of idols; and he enjoined us to speak the truth, to be faithful to our trusts, to be merciful and to regard the rights of the neighbors and kith and kin; he forbade us to speak evil of women, or to eat the substance of orphans; he ordered us to flee from the vices, and to abstain from evil; to offer prayers, to render alms, and to observe fast. "We have believed in him, we have accepted his teachings and his injunctions to worship Allah, and not to associate anything with Him, and we have allowed what $\mathrm{He}$ has allowed, and prohibited what He has prohibited. "For this reason, our people have risen against us, have persecuted us in order to make us forsake the worship of Allah and return to the worship of idols and other abominations. They have tortured and injured us, until finding no safety among them; we have come to your country, and hope you will protect us from oppression [ [ ]"”.

\section{THE RELATIONSHIP BETWEEN GOD (ALLAH) AND THE WORLD}

The relationship between Allah and the world is that of the Creator and the created, Master and servant. Allah says (interpretation of the meaning): "To Him belongs all that is in the heavens and on earth: for verily Allah, $\mathrm{He}$ is free of all wants, Worthy of all

${ }^{3}$ Safi-ur-Rahman al-Mubarakpuri, Ar-Raheeq alMakhtum (The Sealed Nectar): Biography of the Noble Prophet (peace and blessings be upon him), Saudi Arabia, UK, USA, Pakistan: Maktaba Dar-us-Salam Publishers and Distributors, 1996, p. 103. 
Praise." (Qur'an, 22:64). It is quite obvious from this verse that Allah owns everything without being in need of any of His creation. According to the following verses, the entire universe and the creation within it acknowledges Allah's rububiyyah (lordship) and uluhiyyah (divinity). This means, it praises Him, prostrates before Him and follows His orders:

"Seest thou not that it is Allah Whose praises all beings in the heavens and on earth do celebrate, and the birds (of the air) with wings outspread? Each one knows its own (mode of) prayer and praise. And Allah knows well all that they do." (Qur'an, 24:41).

"Whatever beings there are in the heavens and the earth do prostrate themselves to Allah (Acknowledging subjection), with good-will or in spite of themselves: so do their shadows in the morning and evenings." (Qur'an, 13:15).

"And the sun runs his course for a period determined for him: that is the decree of (Him), the Exalted in Might, the All-Knowing. And the Moon, We have measured for her mansions (to traverse) till she returns like the old (and withered) lower part of a date-stalk. It is not permitted to the Sun to catch up the Moon, nor can the Night outstrip the Day: Each (just) swims along in (its own) orbit (according to Law)." (Qur'an, 36:3840).

The submission of the universe to Allah is an indication that its creation is for a definite purpose: "Not for (idle) sport did We create the heavens and the earth and all that is between!" (Qur'an, 21:16). AlGhafilun (the negligent and heedless) are those who are unmindful of Allah and the purpose of their creation.

It is mentioned in numerous verses of the Qur'an that the universe and the creation within it is ayat, evidence of Allah's Existence; a reflection of His infinite might and greatness. For example, Allah says (interpretation of the meaning): "Among His Signs are the Night and the Day, and the Sun and the Moon. Adore not the sun and the moon, but adore Allah, Who created them, if it is Him ye wish to serve." (Qur'an, 41:37). Hence, Allah's Existence is a manifest reality.

THE RELATIONSHIP BETWEEN ALDUNYA (THE PHYSICAL WORLD) AND AL-AKHIRAH (THE SPIRITUAL WORLD OR THE HEREAFTER)

The following supplication defines the Islamic perception of al-Dunya and al-Akhirah and their interrelationship: "Our Lord! Give us good in this world and good in the Hereafter, and defend us from the torment of the Fire!" (Qur'an, 2:201). We can deduce the following lessons from this supplication: first, wellbeing in this worldly life and in the hereafter life is the goal of human endeavours; second, well-being is granted by Allah, the Lord of the worlds; third, the Islamic perspective of well-being is transcendental; last but not least, well-being is one of basic needs of life. It encompasses everything by means of which human beings may seek happiness in both this world and world hereafter. These include good health, knowledge, good shelter, adequate food, good infrastructure, and many more. Allah has bestowed on human beings the resources to utilize in developing the earth and He has assigned them duties and rights. Well-being in alDunya and al-Akhirah is dependent on the fulfillment of one's duties towards Allah, oneself, the society and the environment and this requires understanding the rights each of these have upon us.

Ibn 'Umar reported that the Prophet (peace and blessings be upon him) said: "All of you are shepherds and each of you is responsible for his flock. A man is the shepherd of the people of his house and he is responsible. A woman is the shepherd of the house of her husband and she is responsible. Each of you is a shepherd and each is responsible for his flock [ $\left.{ }^{4}\right]^{\prime}$ '.

It is evident in the foregone verse (Qur'an, $2: 201)$ that Islam is not an ascetic religion that teaches its followers to abandon the affairs of this world and concentrate on the spiritual matters. On the contrary, it advocates moderation and balance between al-Dunya and al-Akhirah. This is because a human being is made up of body and soul and each has its needs. Fulfillment of the needs of both body and soul is what is meant by moderation and balance. Allah says:

"O ye who believe! When the call is proclaimed to prayer on Friday (the Day of Assembly), hasten earnestly to the Remembrance of Allah, and leave off business (and traffic): That is best for you if ye but knew! And when the Prayer is finished, then may ye disperse through the land, and seek of the Bounty of Allah. and celebrate the Praises of Allah often (and without stint): that ye may prosper.” (Qur'an, 62:10).

\footnotetext{
${ }^{4}$ Abu al-Husayn Muslim ibn al-Hajjaj Qushayri alNisaburi, Sahih Muslim, translated by Abdul Hamid Siddiqui, kitab al-Ri'ayah (Book of responsibility), bab al-Rajulu ra'in fi ahlih (Chapter on a man is the shepherd of his family). Retrieved from: https://sunnah.com/muslim
} 
In the above verse a Muslim is urged to attend salat al-Jum'ah, Friday Prayer, and then seek the bounties of this world. Hence, being a Muslim means being dutiful to Allah and responsible towards oneself, fellow human beings, other living creatures on earth and the environment. The Prophet (peace and blessings be upon him) was the best example of a moderate and balanced life. He would perform salat, help his wives and take an active role in the society; he would assist the needy, visit the sick and teach the community how to be well in this worldly life and the hereafter. Now let us take a look at some of the verses and hadith on moderation and balance between dunya and akhirah or body and spirit.

Narrated 'Abdullah bin 'Amr bin al'As: Allah's Messenger (peace and blessings be upon him) said: "O 'Abdullah! Have I not been formed that you fast all the day and stand in prayer all night?" I said, "Yes, O Allah's Messenger (peace and blessings be upon him)!" He said: "Do not do that! Observe the fast sometimes and also leave them (the fast) at other times; stand up for the prayer at night and also sleep at night. Your body has a right over you, your eyes have a right over you and your wife has a right over you $\left[{ }^{5}\right] . "$

Narrated al-Aswad: I asked 'A'ishah (may Allah be pleased with her):

"What kinds of things did the Prophet (peace and blessings be upon him) used to do in his house?" She replied, "He worked for his family, meaning in the service of his family. However, when it the time for prayer came, he went out to the prayer" [ $[6]$ ".

Narrated Abu Hurayra (may Allah be pleased with her): Allah's Messenger (peace and blessings be upon him) said: "The deeds of anyone of you will not save you (from the (Hell) Fire)." They said, "Even you (will not be saved by your deeds), $\mathrm{O}$ Allah's Messenger (peace and blessings be upon him)?" He said, "No, even I (will not be saved) unless

\footnotetext{
${ }^{5} \mathrm{Abu}$ 'Abd Allah Muhammad ibn Isma'il al-Bukhari, Sahih al-Bukhari. translated by Muhammad Muhsin Khan, kitab al-Nikah (Book of wedlock, marriage), bab li jawjika 'alayka haqq (Chapter on your wife has a right over you).Riyadh: Darussalam publishers and distributors, 1997.

${ }^{6}$ Al-Bukhari, Sahih al-Bukhari, kitab al-Azan, bab
} man kana fi hajati ahlihi fa 'uqimat al-Salat fa kharaja. and until Allah bestows His Mercy on me. Therefore, do good deeds properly, sincerely and moderately, and worship Allah in the forenoon and in the afternoon and during a part of the night, and always adopt a middle, moderate, regular course whereby you will reach your target (Paradise) [ $\left.{ }^{7}\right]$."

The duty to earn a living is incumbent upon every adult Muslim who is healthy and sane. The Prophet (peace and blessings be upon him) was a successful merchant before he assumed the role of a prophet. His trustworthiness in business was the reason why Khadijah, his employer, got married to him. He encouraged farming and agriculture as part and parcel of developing the earth.

In Islam the world is viewed as a passageway or a bridge to the hereafter and a temporary dwelling for human beings to prepare for a better and everlasting life after death: "It is We Who have placed you with authority on earth, and provided you therein with means for the fulfilment of your life: small are the thanks that ye give!" (Qur'an, 7:10). One of the lessons that we can extrapolate from this verse is that the worldly provisions and joyful pleasures are bounties of Allah for which human beings are required to be grateful. They are the means by which happiness in this world and everlasting bliss in the Hereafter life are attained. Allah says (interpretation of the meaning):

"...But seek, with the (wealth) which Allah has bestowed on thee, the Home of the Hereafter, nor forget thy portion in this world: but do thou good, as Allah has been good to thee, and seek not (occasions for) mischief in the land: for Allah loves not those who do mischief.” (Qur'an, 28:77).

In this verse we are commanded to give this world its due share; to develop it. However, we are also cautioned not to be engrossed in its pleasures or allow worries and anxieties distract us from realizing the goal of life or fall short in our duties to Allah. Allah says (interpretation of the meaning):

"O men! Certainly the promise of Allah is true. Let not then this present life deceive you, nor let the Chief Deceiver deceive you about Allah." (Qur'an, 35:5).

"The mutual rivalry for piling up (the good things of this world) diverts you (from the more serious things), until

\footnotetext{
${ }^{7}$ Al-Bukhari, Sahih al-Bukhari, kitab al-Raqaq (Book of making the heart tender), bab al-Qasdi wa alMudawamati 'ala al-'Amal (Chapter on the adoption of a middle course, and the regularity of deeds).
} 
ye visit the graves. But nay, ye soon shall know (the reality). Again, ye soon shall know! Nay, were ye to know with certainty of mind, (ye would beware!) Ye shall certainly see Hell-Fire! Again, ye shall see it with certainty of sight! Then, shall ye be questioned that Day about the joy (ye indulged in!).” (Qur'an, 102:1-8).

The Islamic terms for this world and the next world are Al-Dunya and Al-Akhirah respectively. Etymologically, dunya is derived from dunuww, meaning "what is nearer," or from dani, meaning "what is lower or lesser in terms of its worth as compared to the worth of the coming world $\left[{ }^{8}\right] . "$

Most people prioritize Al-Dunya over AlAkhirah due to ignorance of the reality of the latter. Allah says (interpretation of the meaning):

"Day (behold), ye prefer the life of this world; But the Hereafter is better and more enduring." (Qur'an, 87:16$17)$.

"What is the life of this world but amusement and play? but verily the Home in the Hereafter, that is life indeed, if they but knew." (Qur'an, 29:64).

"The (material) things which ye are given are but the conveniences of this life and the glitter thereof; but that which is with Allah is better and more enduring: will ye not then be wise?" (Qur'an, 28:60).

"O my people! This life of the present is nothing but (temporary) convenience: It is the Hereafter that is the Home that will last." (Qur'an, 40:39).

"Allah doth enlarge, or grant by (strict) measure, the sustenance (which He giveth) to whomsoever He pleaseth. (The wordly) rejoice in the life of this world: But the life of this world is but little comfort in the Hereafter." (Qur'an, 13:26).

In contrast to al-Akhirah, which is the real and everlasting existence, al-Dunya is described as follows: First, its possessions and pleasure are like a drop of water from the ocean (as compared to the Hereafter). Therefore, a true believer in the Hereafter life is the one who restrains his or her desire for the worldly

${ }^{8}$ Sayyid Muhammad Husayn Tabataba'i, The Return to Being: The Treatise on Friendship with God, a translation of Risalat al-Walayah by Fazel Asadi Amjad and Mahdi Dasht Bozorgi, London: ICAS Press, 2009, p. xiii. possessions in the hope of receiving the pleasure of Allah in the Hereafter life. Al-Mustawrid reported: that the Messenger of Allah (peace and blessings be upon him) said: "What is the example of this worldly life in comparison to the Hereafter other than one of you dipping his finger in the sea? Let him see what he brings forth [ $\left.{ }^{9}\right]$." It was narrated that Sahl bin Sa'd (may Allah be pleased with him) said:

"We were with the Messenger of Allah (peace and blessings be upon him) in Dhul-Hulaifah, when we saw a dead sheep lifting its leg (because of bloating). He said: 'Don't you think this is worthless to its owner? By the One in Whose hand is my soul, this world is more worthless to Allah than this (dead sheep) is to its owner. If this world was worth the wing of a mosquito to Allah, the disbeliever would not have a drop to drink from it' [ $\left.{ }^{10}\right]$."

It is understood from this hadith that there is no comparison between al-Dunya, this world, and alAkhirah, the Hereafter. The former is temporary residence, contrary to the latter which is permanent residence and the eternal abode of bliss for alMu'minun, the believers. It is reported that the son of Harun al-Rashid who had led a life of abstinence recited two couplets to his companion Abu Amir Basri as advise to him,

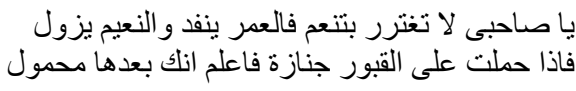

O my companion! Do not be deceived by the bounties of the world, life is coming to an end and bounties will also come to an end.

When you carry a Janazah to the Qabr, then know well that you will certainly be carried after it (one day) $\left[{ }^{11}\right]$.

${ }^{9}$ Sahih Muslim, kitab al-Jannah wa sifat na'imiha wa ahliha, bab fana'u al-Dunya wa bayan al-Hashr yawm al-Qiyamah.2858.

${ }^{10}$ Yahya bin Sharaf Al-Nawawi Al-Damashqi Abu Zakariyyah, Riyad al-Salihin min hadith sayyidi alMursalin, kitab al-Muqaddimat (The book of miscellany), bab fadhli al-Zuhdi fi al-Dunya wa alHathu 'ala al-Taqalluli minha fa fadhli al-Faqr (chapter on excellence of leading an ascetic life, and virtues of simple life), Cairo: Dar ibn Jawzi 1421 A.H.; Abu Abdullah Muhammad bin Yazid bin Majah al-Qazwini, Sunan Ibn Majah, Darl al-Risalah al-'Alamiyyah, kitab al-Zuhd, Hadith 476.

${ }^{11}$ Mohammed Desa (01/12/2014), "The world is not even equivalent to the wing of a mosquito". Retrieved on December 5, 2020 from: https://www.ka.org.za/content/world-not-evenequivalent-wing-mosquito 
Second, its pleasures are lahw, a diversion, meaning they have the potency to divert a person from transcendental pleasure $\left[{ }^{12}\right]$, mata' al-Ghurur, delusion, and qalil, short, they are bound to end sometime soon just like a piece of ice melting in the sun. Hence, we should always be wary of not having our minds fall prey to its adornments. Allah says (interpretation of the meaning):

"Every soul shall have a taste of death: And only on the Day of Judgment shall you be paid your full recompense. Only he who is saved far from the Fire and admitted to the Garden will have attained the object (of Life): For the life of this world is but goods and chattels of deception." (Qur'an, 3:185).

"Know ye (all), that the life of this world is but play and amusement, pomp and mutual boasting and multiplying, (in rivalry) among yourselves, riches and children. Here is a similitude: How rain and the growth which it brings forth, delight (the hearts of) the tillers; soon it withers; thou wilt see it grow yellow; then it becomes dry and crumbles away. But in the Hereafter is a Penalty severe (for the devotees of wrong). And Forgiveness from Allah and (His) Good Pleasure (for the devotees of Allah). And what is the life of this world, but goods and chattels of deception - mata' alGhurur?" (Qur'an, 57:20).

The Qur'anic concept mata' al-Ghurur refers to transitory enjoyment $\left[{ }^{13}\right]$. Literally, it refers to "a cloth that women normally use in the kitchen to wipe and clean the kitchen area," meaning that it is very low. Being lowly, however, does not mean that al-Dunya is worthless. Al-Alusi mentions that Sa'id bin Jubayr (may Allah be pleased with him) is reported to have said that al-Dunya, this world, its comforts and luxuries are worthless if they distract a person from seeking alAkhirah, the Hereafter; that is, if they detach a person from Allah and make him or her unmindful of alAkhirah. They are, however, praiseworthy and worthwhile if they are used to attain ridhwanullah, Allah's pleasure, and eternal life in the Hereafter $\left[{ }^{14}\right]$.

\footnotetext{
${ }^{12}$ Tabataba'i, The Return to Being: The Treatise on Friendship with God, p. xiv.

${ }^{13}$ Mahmud Shukri al-Alusi al-Baghdadi Shihab alDin, Ruh al-Ma 'ani fi tafsir al-Qur'ani al- 'Azimi wa alSab' $i$ al-Mathani, Beirut: Idaratu al-Tiba'ati alMuniriyyah, vol.4, pp.146-147.

${ }^{14}$ Ibid, vol. 27, p.185.
}

In the following hadith we are advised to perceive this world as a transit or a place where we stop over to collect as much provision as possible before we reach our final destination and to live in it as strangers, having a short hope - Qasr al-Amal - or avoiding having hopes that we will live long - Tul al-Amal:

Ibn 'Umar reported: The Messenger of Allah (peace and blessings be upon him) said: "Be in this world as if you were a stranger or a traveller along a path." Ibn Umar would say: "If you make it to the evening, do not wait for the morning. If you make it to the morning, do not wait for the evening. Take from your health for your sickness, and from your life for your death $\left[{ }^{15}\right]$."

It is understood from this hadith that this world is not a home where one should feel entirely happy or a place where one's heart should be tied. The real home of human beings is the world hereafter; it is their eternal abode.

We are also advised to practice al-Zuhd and alWara' in dealing with al-Dunya, this world, and its pleasures. Ibn al-Qayyim (may Allah be pleased with him) said, "I heard Shaykh al-Islam ibn Taymiyyah say, 'al-Zuhd entails abandoning what does not bring about benefit in the Hereafter while al-Wara' (abandoning a part of the permissible for fear of falling into the impermissible) entails abandoning what one fears its consequences in the Hereafter' $\left[{ }^{16}\right]$."

\section{THE RELATIONSHIP BETWEEN MAN AND NATURE/THE PHYSICAL WORLD}

Allah created this world as the source of Man's livelihood and made its possessions as the beautification of this life and Man's pleasure and enjoyment within the prescribed limits: “...And for you on the earth is a place of settlement and enjoyment for a time." (Qur'an, 7:24) $\left[{ }^{17}\right]$; "That which is on earth we have made but as a glittering show for the earth, in order that We may test them - as to which of them are best in conduct." (Qur'an, 18:7). Here it is understood that Allah elevated the status of Man; He preferred him over all the other creatures: "We have honoured the

${ }^{15}$ Al-Bukhari, Sahih al-Bukhari, kitab al-Raqaq, bab qawl al-Nabiyyi salla Allahu 'alayhi wa sallam kun fi al-Dunya ka annaka gharib aw 'abir al-Sabil, hadith 6053.

${ }^{16}$ Shams al-Din Abu 'Abd Allah Muhammad ibn Abi Bakr ibn Qayyim al-Jawziyyah, Madarij al-Salikin byna manazil iyyaka na'budu wa iyyaka nasta'in (Ranks of the Divine Seekers), vol.2, edited by 'Imad 'Amir, Cairo: Dar al-Hadith, 1426 A.H./2005 A.D., p.11.

${ }^{17}$ Saheeh International (ed.), The Qur'an English Meanings, Jeddah: Al-Muntada al-Islami, 2004. 
sons of Adam; provided them with transport on land and sea; given them for sustenance things good and pure; and conferred on them special favours, above a great part of our creation." (Qur'an, 17:70). Aside from that He made him the custodian or caretaker of the earth. Therefore, he is duty bound to:

First, acknowledge Allah as the Creator, Sustainer and Owner of everything and thank Him by using the worldly things to worship and obey Him. Allah says (interpretation of the meaning):

"See they not that it is We Who have created for them - among the things which Our hands have fashioned cattle, which are under their dominion? And that $\mathrm{We}$ have subjected them to their (use)? of them some do carry them and some they eat: And they have (other) profits from them (besides), and they get (milk) to drink. Will they not then be grateful?" (Qur'an, 36:71-73).

Second, treat all creatures who live upon the earth with mercy. Narrated 'Abd Allah ibn 'Amr ibn al'As: The Prophet (peace and blessings be upon him) said: "The Compassionate One has mercy on those who are merciful. If you show mercy to those who are on the earth, He Who is in the heaven will show mercy to you $\left[{ }^{18}\right] . "$

Third, use the resources of the earth to develop himself while ensuring that the earth remains habitable for humans and other living creatures now and in the future. He is forbidden from exploiting the earth for his personal greed or get obsessed with worldly possessions at the expense of remembrance and obedience of Allah.

"It is He Who hath made you khala'if

- (His) agents, inheritors of the earth:

He hath raised you in ranks, some above others: that He may try you in the gifts He hath given you: for thy Lord is quick in punishment: yet He is indeed Oft-forgiving, Most Merciful.” (Qur'an, 6:165).

The term khalai'if which is translated as 'inheritors of the earth' implies that the earth has been inhabited by many nations that are now gone with their achievements: "That was a people that hath passed away. They shall reap the fruit of what they did, and ye of what ye do! Of their merits there is no question in your case" (Qur'an, 2:141). The passing away of nations simply indicates that they were not the masters of the earth and that every nation has an appointed term: "To every people is a term appointed: when their term

\footnotetext{
${ }^{18}$ Imam Hafiz Abu Dawud Sulaiman bin Ash'ath, Sunan Abi Dawud, kitab al-Adab (Book of etiquette),
} bab fi al-Rahmah (Chapter on mercy). is reached, not an hour can they cause delay, nor (an hour) can they advance (it in anticipation)." (Qur'an, 7:34). Therefore, human beings are urged to behave morally in respect to the earth. They are the earth builders and caretakers, and not earth destroyers. They must ensure that their activities do not cause damage to the environment. The Islamic concept for building or development of the earth is i'mar al-Ard, which is intimately connected to the concept of $i s l a h$, meaning to 'reform' or 'restore.' Hence, Earth restoration is one of human responsibilities.

Behaving morally in respect of the earth means to avoid wasting its resources, respect others' right to the world resources and avoid fasad, that is, spreading of evil and corruption on the earth. This includes littering, deforestation, pollution, etc. Allah says (interpretation of the meaning):

"O Children of Adam! wear your beautiful apparel at every time and place of prayer: eat and drink: But waste not by excess, for Allah loveth not the wasters." (Qur'an, 7:31).

"So eat and drink of the sustenance provided by Allah, and do no evil nor mischief on the (face of the) earth." (Qur'an, 2:60).

"Do no mischief on the earth, after it hath been set in order, but call on Him with fear and longing (in your hearts): for the Mercy of Allah is (always) near to those who do good." (Qur'an, 7:56).

As caretakers of the earth, human beings are responsible not only for themselves but for everything on the earth; they are responsible for the animals, the world's resources including the environment, and the whole earth. Unfortunately, the evil actions of some human beings have resulted into appearance of corruption on land and sea:

"Mischief has appeared on land and sea because of (the meed) that the hands of men have earned, that (Allah) may give them a taste of some of their deeds: in order that they may turn back (from Evil)." (Qur'an, $30: 41)$.

The responsibility charged to human beings, which is to take care of earth, is termed as amanah, trust: "We did indeed offer the Trust to the Heavens and the Earth and the Mountains; but they refused to undertake it, being afraid thereof: but man undertook it; He was indeed unjust and foolish" (Qur'an, 33:72).

While 'ibadah is a concept that explains the relationship between the creation (human beings and others) and the Creator, Allah, taskhir explains the relationship between human beings and nature or the 
world. It generally denotes subjugation of nature or the world to human beings. It is the principle governing the relationship between humans and nature. Allah says (interpretation of the meaning):

"Do ye not see that Allah has subjected to your (use) (sakhkhara lakum) all things in the heavens and on earth, and has made his bounties flow to you in exceeding measure, (both) seen and unseen? Yet there are among men those who dispute about Allah, without knowledge and without guidance, and without a Book to enlighten them!" (Qur'an, 31:20).

"He Who has, made for you the earth like a carpet spread out; has enabled you to go about therein by roads (and channels); and has sent down water from the sky. With it have We produced diverse pairs of plants each separate from the others." (Qur'an, 20:53).

If the earth or nature were not subdued to Allah's command and made serviceable to human beings, it would be impossible for them to perform their duties ('ibadah) and to play their role as stewards or guardians of earth (khala'if). Additionally, their life on earth wouldn't be possible; they wouldn't know the time, they wouldn't have food, water, shelter, clothing, etc., and they wouldn't be able to move from one place to another. Therefore, there would be no development and no civilization. In the following verse Allah mentions some of His favours upon human beings so that they may show gratitude to Him:

"And cattle He has created for you (men): from them ye derive warmth, and numerous benefits, and of their (meat) ye eat. And ye have a sense of pride and beauty in them as ye drive them home in the evening, and as ye lead them forth to pasture in the morning. And they carry your heavy loads to lands that ye could not (otherwise) reach except with souls distressed: for your Lord is indeed Most Kind, Most Merciful, and ( $\mathrm{He}$ has created) horses, mules, and donkeys, for you to ride and use for show; and $\mathrm{He}$ has created (other) things of which ye have no knowledge. And unto Allah leads straight the Way, but there are ways that turn aside: if Allah had willed, He could have guided all of you. It is He who sends down rain from the sky: from it ye drink, and out of it (grows) the vegetation on which ye feed your cattle. With it He produces for you corn, olives, date-palms, grapes and every kind of fruit: verily in this is a sign for those who give thought. He has made subject to you the Night and the Day; the sun and the moon; and the stars are in subjection by His Command: verily in this are Signs for men who are wise. And the things on this earth which He has multiplied in varying colours (and qualities): verily in this is a sign for men who celebrate the praises of Allah (in gratitude). It is He Who has made the sea subject, that ye may eat thereof flesh that is fresh and tender, and that ye may extract therefrom ornaments to wear; and thou seest the ships therein that plough the waves, that ye may seek (thus) of the bounty of Allah and that ye may be grateful. And He has set up on the earth mountains standing firm, lest it should shake with you; and rivers and roads; that ye may guide yourselves; And marks and sign-posts; and by the stars (men) guide themselves. Is then $\mathrm{He}$ Who creates like one that creates not? Will ye not receive admonition? If ye would count up the favours of Allah, never would ye be able to number them: for Allah is Oft-Forgiving, Most Merciful. And Allah doth know what ye conceal, and what ye reveal." (Qur'an, 16: 5-19).

By making everything in the universe at human beings' service and benefit, Allah has exalted their position. He says:

"We have honoured the sons of Adam; provided them with transport on land and sea; given them for sustenance things good and pure; and conferred on them special favours, above a great part of our creation." (Qur'an, 17:70).

He has honoured human beings by appointing them as the guardians of this world and the executors of His laws on earth. He has granted them the ability to transform nature into whatever form they want for beauty and convenience. However, He has also warned them from fasad (disorder, corruption, overexploitation of environment), fisq (transgression of the bounds set by Allah or committing any of the major sins), israf (wastefulness), taraf (indulgence in pleasure without moral limit) and shirk (associating partners with Allah.) These were the causes of the destruction of many nations in the past. 
It must be noted that the material goods of this life are a divine blessing to human beings for which they should be grateful. Allah says (interpretation of the meaning): "It is He Who hath created for you all things that are on earth...." (Qur'an, 2:29). They are bestowed upon human beings for use within a set of boundaries to fulfill both their physical and spiritual needs. Allah says (interpretation of the meaning): "...Eat of the Sustenance (provided) by your Lord, and be grateful to Him..." (Qur'an, 34:15). Many nations were destroyed because they transgressed the boundaries; they made the attainment of the material things of this world the sole object of their life. Consequently, they became boastful.

\section{THE RELATIONSHIP BETWEEN MAN AND MAN (INTERPERSONAL RELATIONSHIP)}

Islam did not come to homogenize cultures. Rather, it came to acknowledge and value cultural diversity as one of the great signs of Allah. Allah says (interpretation of the meaning): "And among His Signs is the creation of the heavens and the earth, and the variations in your languages and your colours: verily in that are Signs for those who know.” (Qur'an, 30:22).

All human beings are children of Adam and Hawa (Eve) created from clay by One and the same God, Allah, Who has conferred on each one of them a title of honour and dignity. Hence, no individual, race or ethnicity has a right to claim superiority over other individuals, races or ethnicities based on skin colour, physical traits, ancestry or material achievements. Allah says (interpretation of the meaning):

"O mankind! We created you from a single (pair) of a male and a female, and made you into nations and tribes, that ye may know each other (not that ye may despise (each other) lita'arafu. Verily the most honoured of you in the sight of Allah is (he who is) the most righteous of you. And Allah has full knowledge and is well acquainted (with all things)." (Qur'an, 49:13).

This verse mentions two things that deserve attention: first, ta 'araf as the reason for gender binary and ethnic and racial diversity, and the basis of human relationships and interaction with one another; second, taqwa as the basis of human nobility and honour, and the basis of human relationship with Allah. What is taqwa? And, what is ta' aruf?

'Umar ibn al-Khattab (may Allah be pleased with him) wanted to understand the meaning of taqwa. Hence, he asked 'Ubayy Ibn Ka'ab (may Allah be pleased with him) to explain it to him. 'Ubayy responded asking: "Have you ever taken a thorny path?" "Umar replied in the affirmative. Then 'Ubayy asked again: "So how did you travel along this thorny path?" 'Umar (may Allah be pleased with him) replied: "I rolled up my garment and was cautious as to where I would tread to avoid being pricked by the thorns." So 'Ubayy responded and said: "This is taqwa." This is a very good and precise illustration of how people of taqwa act; they are always "cautious and careful with where they tread, not out of fear of stepping on a thorn, but out of fear of stepping into what Allah SWT has prohibited $\left[{ }^{19}\right]$."

In the Qur'an Allah instructs human beings to have taqwa towards Him, fitnah (oppression), Hell Fire and the Day of Judgment. For example, He says (interpretation of the meaning):

"The Believers are but a single Brotherhood: So make peace and reconciliation between your two (contending) brothers; and fear Allah, that ye may receive Mercy." (Qur'an, 49:10).

"And fear tumult or oppression, which affecteth not in particular (only) those of you who do wrong: and know that Allah is strict in punishment." (Qur'an, 8:25).

"...then fear the Fire whose fuel is men and stones, which is prepared for those who reject Faith." (Qur'an, 2:24).

"And fear the Day when ye shall be brought back to Allah. Then shall every soul be paid what it earned, and none shall be dealt with unjustly." (Qur'an, 2:281).

Taqwa towards Allah means "to be aware of Him with every action and step one takes;" "to attach one's heart to Him Alone;" and "to be conscious of one's duties to Him."

Taqwa of fitnah or oppression and transgression is "to beware of the consequences of oppression and transgression" of other people's rights. Narrated Ibn 'Abbas: The Prophet (peace and blessings be upon him) sent $\mathrm{Mu}$ 'adh to Yemen and said, "Be afraid, from the curse of the oppressed as there is no screen between his invocation and Allah.",20

Tawqa of Hell Fire means "to place a protective barrier between oneself and Allah's

${ }^{19}$ OnePath Network Inc. (June 01, 2015). What is Taqwa (Piety) in Islam. Retrieved on October 22, 2020 from: https://onepathnetwork.com/what-istaqwa/?gclid=EAIaIQobChMIyKqWv7qp7QIVCZ1LB R39PQAKEAAYASAAEgKCR_D_BwE

${ }^{20}$ Al-Bukhari, Sahih al-Bukhari, kitab al-Mazalim (the book of oppressions), bab al-Ittiqa'i wa al-Hazari min da'wati al-Mazlum (chapter of the curse of the oppressed). 
punishment;" in other words, it is "to save oneself from the punishment of the Hell Fire:

"O ye who believe! save yourselves and your families from a Fire whose fuel is Men and Stones, over which are (appointed) angels stern (and) severe, who flinch not (from executing) the Commands they receive from Allah, but do (precisely) what they are commanded." (Qur'an, 66:6).

Taqwa of the Day of Judgement refers to "being aware of one's accountability to Allah."

In a nutshell, taqwa is "fulfillment of obligations and avoidance of prohibitions and doubtful matters." However, if someone fails to fulfill any of the obligations or commits a wrongdoing, taqwa is "to repent immediately and follow up the bad deed with a good deed."

"And establish regular prayers at the two ends of the day and at the approaches of the night: For those things, that are good remove those that are evil: Be that the word of remembrance to those who remember (their Lord):" (Qur'an, 11:114).

On the authority of Abu Dharr Jundub ibn Junadah and Abu 'Abd al-Rahman $\mathrm{Mu}$ 'adh bin Jabal (may Allah be pleased with them) that the Messenger of Allah (peace and blessings be upon him) said: "Be conscious of Allah wherever you are. Follow the bad deed with a good one to erase it, and engage others with beautiful character $\left[{ }^{21}\right]$.",

The Arabic verb lita 'arafu, which is translated as "that ye may know each other," conveys the following meanings:

1) Foster mutual love and affection.

2) Appreciate each other's cultural differences which are in agreement with al-Shari'ah, Divine Law.

3) Understand and recognize the physical appearance of other ethnicities.

4) Acknowledge the contributions of diverse groups.

5) Acknowledge the rights of others.

6) Strengthen each other.

7) Care for each other.

8) Defend each other.

${ }^{21}$ Yahya bin Sharaf An-Nawawi, The forty hadith of
al-Imam an-Nawawi: Text with explanatory notes,
abridged from Arabic sources by Umm Muhammad,
Jeddah: Abul-Qasim publishing house, 1999, Hadith No. 18.
9) Treat one another with full dignity and honour.

10) Bring about unity through diversity.

11) Live side by side peacefully, orderly and harmoniously.

12) Enjoin each other to do what is virtuous and abstain from what is vicious.

13) Collaborate and cooperate with each other.

14) Accept and honour the natural or factual differences.

15) Behave sensibly with those who are different from you.

16) Learn from one another.

Without all the above mentioned, it is not possible for people of different affiliation (ethnicities, races and religions) to enjoy the harmony of living together (coexist peacefully). Hence, they are unable to achieve a civilization.

Cooperation is an act or instance of working or acting together, or helping each other out to achieve a common purpose, benefit or goal, instead of working separately in competition. Allah says (interpretation of the meaning): "Help ye one another in righteousness and piety, but help ye not one another in sin and rancour: fear Allah. for Allah is strict in punishment." (Qur'an, 5:2). Competition with the goal to dominate, personal ambition, nationalism, self-interest, selfishness and greed are antithesis of cooperation. They promote conflict and divide people.

Cooperation between people is necessary so that they can meet each other's needs. It is through cooperation, rather than conflict, that people achieve a common goal or derive mutual benefits. Cooperation links human beings to each other. It contributes to their knowledge of each other. Throughout history, human beings have depended on one another, cooperated from each other and learnt from one another. Subsequently, this has enabled the development of civilizations and the progress of society.

With reference to equality of human beings, Abu Nadrah (may Allah be pleased with him) reported: The Messenger of Allah (peace and blessings be upon him) said during the middle of the day at the end of the pilgrimage, "O people, your Lord is one and your father Adam is one. There is no favor of an Arab over a foreigner, nor a foreigner over an Arab, and neither white skin over black skin, nor black skin over white skin, except by righteousness. Have I not delivered the message?" They said, "The Messenger of Allah has delivered the message $\left[{ }^{22}\right]$."

It worth mentioning that civilized individuals are those who are noble and cultured; they display high standard mannerisms such as respect, cooperation, tolerance, forgiveness, politeness, modesty, and 
patience; they are very attentive towards how they interact with people of all backgrounds; they are often modest in their demeanour and tend to approach daily life with a great deal of patience. High standard mannerism are essential to human interaction and social solidarity.

Tolerance refers to the willingness of an individual to establish a relationship and co-exist with another individual of a different cultural and social background.

\section{CONCLUSION}

It is clear from the foregone that the Islamic worldview of God, Man and the world is inclusive of the following relationships: first, the relationship between Allah and His creation (Creator-creation relationship); second, the relationship between Man and Man (interpersonal relationship); third, the relationship between Man and the world (Man-world relationship); and fourth, the relationship between al-Dunya (this world) and al-Akhirah (the world hereafter) or Dunya Akhirah relationship. It is understood from what has been described that one of the aims of the Qur'an is to lay a foundation for a purposeful and meaningful life on the earth, and a peaceful life in the Hereafter. 